\title{
No. XVI.-NUDIBRANCHS COLLECTED BY Mr. STANLEY GARDINER FROM THE INDIAN OCEAN IN H.M.S. SEALARK.
}

\author{
By Sir Charles N. E. Eliot, K.C.M.G., C.B. \\ (Communicated by Prof. J. Stanley Gardiner, M.A., F.R.S., F.L.S.)
}

(Plate 25.)

Read 2nd December, 1909.

ThE Nudibranchs collected by Mr. Stanley Gardiner and his assistant, Mr. J. C. F. Fryer, among the islands of the Indian Oceau comprise 28 species and 50 specimens. The list is as follows :-

\begin{tabular}{|c|c|c|}
\hline Nane. & $\begin{array}{c}\text { Locnlity and } \\
\text { number of specimens. }\end{array}$ & Previous records. \\
\hline 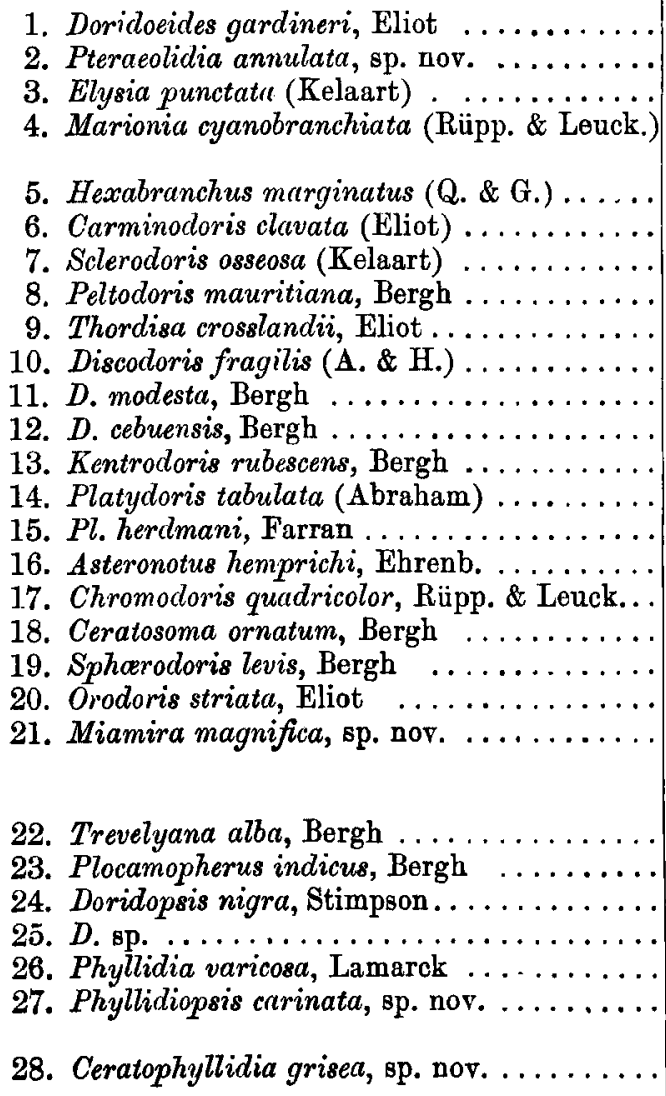 & $\begin{array}{l}\text { Coetivy, } 11 . \\
\text { S. de Malha, } 1 . \\
\text { Coetivy, 1. } \\
\text { Egmont, Reef, } 2 . \\
\text { Amirante, } 2 . \\
\text { Coetivy, } 1 . \\
\text { Coetivy, 1. } \\
\text { Salomon, } 3 . \\
\text { Coetivy, 1. } \\
\text { Lagoon, Diego, } 1 . \\
\text { Coetivy, 1. } \\
\text { Coetivy, 2. } \\
\text { Salomon, 1. } \\
\text { No label found with this. } \\
\text { Amirante, } 2 . \\
\text { Egmont, 1. } \\
\text { Aldabra, 1. } \\
\text { Seychelles, } 1 . \\
\text { Coetivy, } 2 . \\
\text { Praslin, Reef, } 4 . \\
\text { Seychelles, 1. } \\
\\
\text { Cargados Carajos, } 1 . \\
\text { Coetivy, 1. } \\
\text { Coetivy, 3. } \\
\text { Coetivy, 1. } \\
\text { Salomon, 1; Aldabra, } 1 . \\
\text { Amirante, 1. } \\
\text { Coetivy, 1. }\end{array}$ & $\begin{array}{l}\text { Rotuma. } \\
\text { India, Polynesia, E. Africa. } \\
\text { Red Sea. Probably =M. arborescens, } \\
\text { which is common in Indo-Pac. area. } \\
\text { Indo-Pacific, especially E. Africa. } \\
\text { E. Africa. } \\
\text { India, E. Africa. } \\
\text { Mauritius. } \\
\text { Zanzibar. } \\
\text { India, Ceylon, Samoa, and Philippines. } \\
\text { Philippines. } \\
\text { Philippines. } \\
\text { Philippines and E. Africa. } \\
\text { Japan, E. Africa. } \\
\text { Ceylon. } \\
\text { Common in Indo-Pacific. } \\
\text { Amboina. } \\
\text { E. Africa and Malay Archipelago. } \\
\text { Zanzibar. } \\
\text { The nearly allied M. sinuata (= no- } \\
\text { bilis) has been found in the Malay } \\
\text { Archipelago and Samoa. } \\
\text { Malay Archipelago. } \\
\text { Amboina. } \\
\text { Common in Indo-Pacific. } \\
\text { Common in Indo-Pacific. } \\
\text { Allied to Ph. papilligera from Gulf } \\
\text { of Mexico. } \\
\text { Allied to } C \text { africana from E. Africa. }\end{array}$ \\
\hline
\end{tabular}


Of the above, no fewer than 17 species and 37 specimens come from the Seychelles Archipelago (chiefly Coetivy and Amirante). Six species and nine specimens come from the Chagos Archipelago (Salomon and Egmont).

I have marked four species as new: Pteraeolidia annulata, Phyllidiopsis carinata, Ceratophyllidia grisea, and Miamira magnifica. It is possible that the last three of these may prove to be merely varieties of Ph. papilligera, Bergh, C. africana, Eliot, and $M$. sinuata, van Hasselt. But even so, they still present points of interest, for the Phyllidiopsis, if not new, is identical with a species found in the Atlantic (Gulf of Mexico); the large soft globules on the back of C. grisea exhibit in a more highly developed form the curious conformation described for $C$. africana; and the coloration of M. magnifica is remarkable for its brilliancy even among Indo-Pacific Nudibranchs. The chief morphological interest of the collection lies in the eleven specimens of Doridoeides gardineri, a doridiform cladohepatic nudibranch of most unusual structure, which has already been described in detail by Mr. Fvans and myself in the 'Quarterly Journal of Microscopical Science' (March 1908).

The lacunæ in the collection are striking. The common Indo-Pacific genera Melibe, Bornella, Nembrotha, and Placobranchus are entirely absent. There is only one Eolid, and the genera Elysia, Asteronotus, Chromodoris, Ceratosoma, Trevelyana, and Phyllidia, usually numerous in these waters, are represented by one specimen each.

The Indo-Pacific, especially the shores of East Africa, Ceylon, and the Malay Archipelago, is known as the region where Nudibranchs attain their greatest size and brilliancy. Judged by this standard the individuals in the present collection are small, especially Scleradoris, Carminodoris, Platydoris, Asteronotus, Ceratosoma, Phyllidia, and Hexabranchus. Only Thordisa, Kentrodoris, Miamira, and Orodoris can be said to be represented by well-grown specimens.

Deductions as to the distribution of Nudibranchs can be made from a single collection only with great reserve. Mr. Gardiner informs me that he did little reef-collecting in the Seychelles, except at Coetivy, which may explain the absence of some common forms. Also many species are known to appear on the coast for a few days to spawn and then retire*, so that collecting at different times of the year may yield different results both as to the size of individuals and number of species. The present series of specimens supports a conclusion suggested by collections made previously by Mr. Gardiner in the Maldive and Laccadive Islands, by Mr. Crossland in the Cape Verde Islands, and by myself in Samoa-namely, that the Nudibranch fauna found round archipelagos which have not been united to any considerable mass of land in recent times is usually not so rich as that of neighbouring mainland shores, and does not afford such large specimens. But the collection from Mauritius described by Bergh consists of 32 species and indicates no material difference from the fauna of the East African coast. A small collection from Christmas Island, lying to the south of

* I have observed this habit in Ceratosoma, Melibe, Trevelyana, and various species of Aplysia and Pleurobranchus. 
Java, for which I am indebted to Mr. E. A. Smith, of the British Museum (Natural History), contains :-

1. Phidiana inca, 4 specimens.

2. Phyllidia nobilis, 1 small specimen.

3. Plocamopherus imperialis, 1 small specimen.

4. Five specimens of a Doridopsis, the largest about $20 \mathrm{~mm}$. long. They have a brilliant and elaborate coloration and are probably a new species.

In this list it will be seen that there is a form, $P h$. inca, hitherto known only from the west coast of America. Mr. Gardiner's collection cannot be said with certainty to contain any form which is associated with another region, but the resemblance of Phyllidiopsis carinata to a species from the western tropical Atlantic is very striking.

The colours of the specimens have begun to fade, but when I first received them, many (e.g., Hexabranchus, Thordisa crosslandii, Phyllidia) had preserved in formaline what I know from seeing them in their native haunts to be their natural coloration.

I therefore caused coloured drawings of the more remarkable animals to be made without loss of time, and they are now reproduced.

\section{Doridoeides gardineri, Eliot.}

See Eliot and Evans, in Q. Journ. Micr. Sci. vol. lii. part 2 (March 1908).

This form being considered to be of unusual interest was described separately by Mr. Evans and myself, with a somewhat full account of its anatomical structure and a discussion of its affinities. To this paper the reader is referred for further details, but part of the description there given is now reproduced :-

Eleven specimens labelled Coetivy and preserved in formol. Coetivy is the southernmost island of the Seychelles group, and Mr. Gardiner's notes state that the nudibranchs obtained there were "all from the reefs, which differ from those of the Chagos archipelago in being almost completely covered with Zostera *." It is probable that the animal adheres to the leaves of the Zostera and harmonizes with them in colour.

The natural shape seems to be flat and nearly circular, but the preserved specimens are bent in various ways and have the edges turned inwards. One which seems to have kept its form fairly well is $10 \mathrm{~mm}$. long, 9 broad, and 2 high. These are the average dimensions of the consignment. In the individual mentioned the foot is $6 \mathrm{~mm}$. long and 3 broad, but was evidently much wider in life as the margins are bent and rolled up. The free part of the mantle starting from its junction with the foot is 3.5 wide. It can be seen from the outside that about $2.5 \mathrm{~mm}$. of this space are filled with dark internal organs and that only about $1 \mathrm{~mm}$. of it corresponds to the mantle margin generally found in Dorids. 'The genital orifice is about $4 \mathrm{~mm}$. from the anterior end, and the anus is about $2 \mathrm{~mm}$. behind it.

The animals are of a greyish-green colour, a little darker in the centre where the internal organs show through, and lighter at the edges where there are none. Practically

* [This is a mistake for Cymodocea.-J. S. G.] 
the coloration is uniform, though some specimens are lighter than others and the under side is usually rather lighter than the upper.

To the naked eye the dorsal surface appears to be smooth, but under a low power can be seen to be covered with small warts of various sizes, sometimes connected by an irregular reticulation and with minute pits between them. There is no median ridge and no trace of a branchial opening. The integuments are devoid of spines. The dorsal epidermis is thick and consists of several layers of cells : it is profusely pitted with mucus glands and in many places rises into folds. On the under surface of the mantle and on the foot the epidermis is thin, but the foot is highly glandular. It contains both epidermal glands and subepidermal glands with granular contents and communicating with the exterior by long necks.

The rhinophores are completely retractile. Their pockets are simple holes without sheaths visible to the naked eye; but in the sections it can be seen that the margins are slightly raised. As preserved, the pockets are often closed. When retracted the rhinophores often exhibit a few (6-7) strong transverse wrinkles or furrows, and these were also present in the specimen obtained at Rotuma. But they are probably not real perfoliations, since they are absent when the rhinophores are completely exserted. In such cases the outline is even and cylindrical. There are no oral tentacles and nothing which can be called a head. In some specimens the mouth is a simple orifice above the foot, but in others there is a sort of snout. It would seem, however, that this protrusion is due to artificial causes and is not a natural and permanent structure. There are no lamellæ on the under side of the mantle as in Phyllidia, \&c., but it is uneven and in some cases presents ridges and bulges probably caused by the hepatic follicles. The foot is large, with ample expanded margins. The anterior margin is straight and not grooved.

When the internal cavity is opened, the central nervous system is seen lying on the top of the œsophagus and surrounding it. There is no trace of a blood-gland. The cerebro-pleural ganglia are rather large and elliptical; externally they show no division, but a section indicates that the ganglionic mass is of dual origin and divided internally by a constriction into two nearly equal ellipsoids. The pedal ganglia are also elliptical and lie below and rather behind the cerebro-pleural. The buccal ganglia are rather large, close to the pedal ganglia and also close to one another. No gastroœsophageal ganglia could be found and no otocysts. The eyes are black and lie near the base of the rhinophores on the olfactory ganglia, the optic and olfactory nerves being apparently fused. This arrangement is unusual, but something similar may be seen in Bergh's figure (Malac. Unters. in Semper's Reisen, Heft xv. pl. lxxi. fig. 17) of the nervous system of Tritonia (Candiella) plebeia, where the optic and olfactory nerves are joined for a considerable distance and separate only in their upper portion. The pigment layer of the eye lines a cup formed of a few large retinal cells, from which fibres run into the olfactory nerve at the base of its ganglion.

The jaws are yellowish but not deeply pigmented in any part, moderately convex, not very broad, united at the top by a hinge, and provided with short processes. The edge is armed with a row of very distinct projections with spatulate tips. Near the end 
of the row they appear thin and filamentous, possibly because they have become worn or folded on themselves. The radula consists of about twenty-six rows, one or two of which are imperfectly developed and shadowy, with a constant formula of 4.1 .4 . The teeth are neatly arranged in a close-fitting mosaic. The base of the large median tooth, which is arched and hollowed out behind, is nearly twice as broad as all the four laterals together. It bears a single cusp, large and only slightly bent downwards. The first lateral is about three-fifths the length of the median tooth, but only a quarter of its breadth, with a single hamate cusp. The second and third laterals are similar but slightly smaller and more bent. The outermost tooth is considerably smaller but more erect and stands up conspicuously at either end of the row. There are two salivary glands; their distal portions are expanded and spread over the genitalia and stomach. The left is much larger than the right. The remaining portion of each gland is bandlike and terminates in a long thin duct which passes through the nerve collar and enters the posterior part of the buccal mass. Several glands, probably ptyaline, open into the buccal cavity, but they are embedded in the wall of the cavity and are not visible on its outer surface.

The oesophagus is not long, and leads straight into the stomach, which is divided into two parts by a constriction more marked on the right than on the left side. There is no structural difference in the walls of these two divisions, and neither contains any spines or plates, but as the hepatic ducts all open into the second division, the first should perhaps be regarded as a dilatation of the csophagus. Neither contained any solid food in any specimen. The intestine issues from the mid-dorsal surface of the second division and, after describing a broad loop backwards and downwards, runs to the anal opening, which is an inconspicuous papilla on the right side, lying below the mantle edge and just at the point where it joins the body. The loop of the intestine bears a single longitudinal ridge resembling the typhlosole found in Lumbricus.

The stomach receives three hepatic ducts: one on the right, close to the exit of the intestine; one on the left, not quite opposite to it, but a little posterior ; and one behind. The posterior and left ducts bifurcate close to the stomach and then ramify into branches composed of follicles which are not only found in the body cavity but enter the body wall and dorsal integuments, extending to within a short distance of the mantle brim. The arrangement and extent of the right duct is essentially the same, but the follicles are developed more luxuriously on this side than on the left, and the bifurcation is less clear, although the duct runs in two directions, backwards and forwards. The right and posterior branches anastomose, but though the right and left branches almost meet anteriorly they seem not to communicate, nor do the posterior and left branches. All three branches consist of variously-shaped follicles communicating with one another, so as to offer a continuous passage but not forming a cylindrical tube except in the main ducts. For some distance from the point of entry into the stomach the walls of the main duct bear folds which dovetail into one another in the middle of the lumen and form a valve or strainer.

The cells which line the hepatic lobules are columnar or cubical and highly granular. Some are in a distended condition, others are attached to the wall of the lobule only by 
a strand or are free in its cavity. It would seem, therefore, that some of the liver cells are excretory in function, and are dropped into the follicle as they become extended with excreted material.

The heart lies somewhat to the right of the median line. The walls are thin, and not strong. From the ventricle issue the anterior and posterior aortas, but the aortic system is not much developed, as is perhaps natural in an animal that has no gills. The arteries are thin, and do not extend beyond the level of the genital orifice in front and of the anus behind. The musculature of the ventricle also is feebly developed. The venous system is extensive and the veins are provided with valves not only near the heart but in parts far from it, e.g. throughout the length of the lateral veins and venules and between the blood lacunæ of the foot. The auricle has a large extension on the left, enclosed by a corresponding extension of the pericardium; it adheres to the anterior part of the ventricle, the line of adhesion being zigzagged, and on the right it is attached to the wall of the pericardium.

The kidney is a shallow chamber lying on the surface of the hermaphrodite gland, and sending downward prolongations between its follicles. In front it bifurcates like the hermaphrodite gland, and is divided behind into a number of irregular tubes by the dorso-ventral muscles and the projecting genital lobes. The renal opening is minute and near the anus. From the reno-pericardial opening a tube passes dorsally through the substance of the kidney and dilates in the median line into a flattened vesicle. Posteriorly this sub-divides into three fine ducts, each opening into the kidney by a minute aperture. The wall of the kidney is formed by a layer of large, clear, cubical cells, the nucleated protoplasmic portion of which is limited to a small quantity at the base of the cell.

The genitalia are large, and occupy most of the right-hand side. The hermaphrodite gland consists of a single undivided mass of roughly triangular shape, bifurcating in front so as to enclose the ampulla and the spermatotheca in the fork. It is traversed by branches of the liver, which enter it from below, by the dorso-ventral muscle bands, and by various prolongations of the blood lacuna of the foot. The kidney also sends prolongations into its upper surface. It presents a series of lobes the outer layers of which are formed by masses of ova. Within each lobe is an ample loculus, larger than the whole mass of ova, containing spermatozoa in all stages of development. But there is no symmetrical arrangement of ovarian follicles round a central male follicle.

The hermaphrodite duct is thin and short, but swells out into an unusually large pear-shaped ampulla which again contracts into a thin tube. After a short straight course this tube bifurcates. The male portion runs forward and describes a complete loop, after which it first dilates into a prostatic portion (but without any trace of a separate prostate gland) and then contracts into a muscular portion, terminating in a thin conical glans penis. No trace of spicules or other armature was found in this or any part of the genitalia. After the main bifurcation dividing the male and female branches, the female branch runs backwards for a little distance as a short tube and then itself bifurcates. A short duct leads to the spermatotheca, which is large, g]obular, and single, no trace of a second receptaculum seminis being found. The walls of the 
spermatotheca are thick and produce a secretion. In some specimens small clumps of spermatozoa are embedded in this secretion. In others all the spermatozoa form a central mass in the main cavity of the spermatotheca. It is possible that the secretion serves to form small packets of spermatozoa or spermatophores. The spermatotheca communicates by a long thin duct with a vaginal opening which lies at the base of the penis. The other division of the female branch enters the mucus* gland, enclosing the albumen * gland, which is smaller. The mucus gland communicates with the exterior directly by a slit-like irregular aperture which lies a little behind the other orifices and is much larger than they are. Only spermatozoa are to be found in the ducts and in the spermatotheca. There are no ova except in the hermaphrodite gland, where they are in process of ripening or nearly ripe.

In all the specimens examined microscopically were found scattered cells which do not seem to form part of the essential bodily structure. They are large and rounded in outline, with vacuolated contents and a large round nucleus. They occur chiefly in the connective tissue spaces, in spaces hollowed out in the dermal muscle layers and among the epidermal cells. The fact that they are absent from the cavities of all the internal organs and from the lacunar blood spaces, and that they are limited to the dorsal regions of the body which are of a deeper green than the ventral surface, suggests that they are of the nature of Zoochlorelle or symbiotic algæ.

It will thus be seen that Doridoeides is an annectant form connecting the Holo- and Cladohepatica. It has the essential features of the latter, for its liver-system is cladohepatic, there is no blood-gland, only one spermatotheca, and the anus is lateral. On the other hand, the shape is doridiform, except that there are no gills whatever, and the genital system is triaulic.

\section{Pteraeolidia annulata, sp. nov. (Plate 25. fig. 13.)}

(For genus, see Bergh, Beitr. zur Kennt. der Aeolidiaden, iii. p. 22, and Eliot, in Proc. Zool. Soc. 1903, vol. i. pp. 255-6.)

Label : "S. de Malha. C 12, fath. 47."

One specimen nearly rolled up into a ball, but $35-40 \mathrm{~mm}$. long if stretched out. Maximum breadth across the back $4 \mathrm{~mm}$. The body is bluish white. The cerata are of much the same colour, but bear below the tip of each a single very distinct ring of carmine. The tips themselves are vivid white. The oral tentacles and rhinophores are carmine. There are no marks or mottlings on the body, but the white follicles of the hermaphrodite gland are visible through the dorsal integuments.

The foot appears to have had tentacular angles in front, but is so much contracted that its structure is uncertain. The oral tentacles are short distinct columns rising from an oral veil. The rhinophores are distinctly perfoliate. The cerata are arranged as is usual in the genera Flabellina and Pteraeolidia, and are set in eleven fairly distinct groups. The first group consists of two rows, the others of a single row only. In the

* The functions of these glands are presumably as indicated by their names, but it is not easy to say which is which. 
larger groups each row contains eight cerata; in the smaller the number is less. Each group is set on a ridge or common base, which is about $4 \mathrm{~mm}$. long and $2 \mathrm{~mm}$. high in the largest groups, and is curved or oblique, extending a little way beyond the side of the body. The largest cerata are $8 \mathrm{~mm}$. long; the outer ones are minute.

The radula is uniseriate and consists of about 70 very broad plates, which are almost pectinate as in Aeolidia, though the denticles are not very numerous, being only 8 or 9 on either side of the central cusp, which is distinct though not very prominent. The posterior portion of each tooth is expanded on either side into a sort of accessory plate (see $\mathrm{Pl}$. 25. fig. 13).

The jaws bear a single row of distinct but irregular denticles, often pointed, but sometimes blunt or square at the tips.

In order to preserve the specimen, which though bent is in good condition, and has kept its colours unusually fresh and distinct, no further dissection was made.

This animal bears a strong superficial resemblance to Kelaart's figure of Eolis bicolor (reproduced in Proc. Zool. Soc. 1906, pl. xlv. fig. 4), which is probably identical with the Samla annuligera described by Bergh in Schauinsland's 'Reise nach der Pacific: Die Opisthobranchier,' pp. 236-239. But eren externally there is some difference, since the number of cerata in each group is greater in this species and the common base is larger. Also the radula consists of a single series of about 70 teeth, whereas Samla has a short radula of 20 rows, each containing three teeth.

The specimen must be referred to Pteraeolidia, but is distinguished from Pt. semperi, a common Pacific form, not only in colour, but also by the length of the radula and the shape of the teeth.

\section{Elysia punctata (Kelaart).}

See Eliot, in Proc. Zool. Soc. 1906, p. 690.

One specimen labelled Coetivy. It is rolled up into a ball as preserved, but would be about $30 \mathrm{~mm}$. long and $15 \mathrm{~mm}$. broad if straightened. The integuments are much decayed, but what remains of the skin is greenish with black dots, which are especially thick on the rhinophores and just in front of the pericardium. The teeth of the radula are not denticulate, and number seven in the ascending portion, six in the descending, and about a dozen in the heap.

\section{Marionia cyanobranchiata (Rüppell \& Leuckart).}

See Eliot, in Journ. Linn. Soc., Zool. vol. xxxi. 1908, pp. 120-2.

Two specimens from Egmont reef. As preserved they are of a light primrose-yellow, with whitish tubercles, which seem to rise in the meshes of a reticulate pattern. But these markings have become very faint. On some of the branchiæe are traces of bluishgreen colour. The measurements as preserved are about 25 by $20 \mathrm{~mm}$, but the animals were no doubt considerably longer and thinner when alive.

The oral veil bears eight simple appendages besides a pair of tentacles. The branchiæ are nine on each side, arborescent and very ample, so that they eutirely hide the 
back. The jaws bear a single row of denticles. The formula of the radula is about $45 \times 25+1+1+1+25$. The stomach is armed with about 70 plates.

This seems to be Rüppell and Leuckart's $\boldsymbol{M}$. cyanobranchiata from the Red Sea, described rather more fully by $\mathrm{Mr}$. Crossland and myself, l.c. It is probably a highlycoloured variety of the widespread Indo-Pacific form called by Bergh $\boldsymbol{M}$. arborescens, but the specific name cyanobranchiata has priority. As far as can be judged from their present condition, these specimens belong to the highly-coloured form.

5. Hexabranchus marginatus, Quoy \& Gaimard.

Two rather small specimens, measuring respectively about 65 and $40 \mathrm{~mm}$. in length, 50 and $35 \mathrm{~mm}$. in breadth. They are labelled "Amirante: depth 25-80 fms."

The specific divisions of Hexabranchus are extremely doubtful, and it is highly probable that all the commoner forms are varieties of a single species, though $H$. adamsii, Gray (=H. punctatus, Bergh), may be entitled to specific rank. The present specimens are probably referable to $H$. marginatus, Q. \& G., which is abundant on the east coast of Africa.

\section{Carminodoris clavata (Eliot).}

= Artachaa clavata, Eliot, in Journ. of Conchology, Oct. 1905, pp. 81-85.

One small specimen, about $30 \mathrm{~mm}$. long and $18 \mathrm{~mm}$. broad, labelled "Coetivy ; Diver : 32 feet." The colour is purplish with lighter mottlings, and the warts on the dorsal surface very flat. The internal and external characters agree with those described by me for Artachae clavata, l. c.

I think, however, that as long as the present genera of Dorids are accepted, this animal should be referred to Carminodoris rather than to Artachea. I did not refer it to the former genus on account of Bergh's statement of the generic characters as "Corpus sat molle, notæo minute papillaturn . . . . radula pleuris multidentatis, dentibus hamatis." This formula does not seem applicable to a hard animal stuaded with large distinct warts and having denticulate teeth. But I have recently had an opportunity of examining the original specimens of Carminodoris blandula in the collection of the Siboga Expedition, and find that in them the dorsal surface is tuberculate and all the teeth denticulate. These specimens and the animal which I previously called Artachea clavata seem to me to belong to the same genus, though to different species. Carminodoris should apparently be defined as possessing a tuberculate back, a labial armature, denticulate teeth, a prostate, and an armature of spines on the male genitalia.

But I am by no means certain that, in a general revision of the Dorididæ, the genus Artachae (1881) ought not to be extended to include the later Carminodoris (1889). For the tuberculate back of Carminodoris seems to dissociate it from Discodoris, to which Bergh allies it. It is not clear whether the type specimen of Artachea had a distinct prostate or not. Bergh says of the vas deferens "Der obere (prostatische) Theil weicher."

I have not had an opportunity of examining the original specimens of Artachae or of Carminodoris mauritiana, Bergh. 
7. Sclerodoris osseosa (Kelaart).

See Alder \& Hancock, in Proc. Zool. Soc. 1864, p. 121 ; Eliot, in Proc. Zool. Soc. 1903, vol. ii. p. 380, and Eliot, in Journal of Linnean Soc., Zoology, vol. xxxi. 1908, p. 113, on Peronodoris and its allies.

One small specimen from Coetivy.

Shape nearly circular. Length $12 \mathrm{~mm}$., breadth 10 . The whole surface of the back, both the ridges and the depressions between them, is covered with minute granulations. The feet and underside are pale yellow. The ground-colour of the back is purplish and produced by a multitude of little dots, but the ridges are yellowish. They consist of one principal ridge running from the rhinophores to the branchiæ and numerous irregular side ridges, which are connected here and there, and often form bumps at the point of junction. The rhinophore-sheaths are raised but closed. The branchial pocket is also closed, but seems to be toothed. On the ridge in front of it is a large flat purplish depression. The integuments are crammed with short spicules, straight or bent and often granulate. The oral tentacles are moderately long and distinct. The anterior margin of the foot is grooved. It is not clear if the upper lamina is notched or not.

There is no labial armature. The formula of the radula is $36 \times$ about 45.0 .45 . The teeth are simply bamate, the outermost are a little irregular.

No spine or other armature was found on the genitalia, but its absence cannot be regarded as certain.

\section{Peltodoris mauritiana, Bergh.}

Bergh, Mal. Unters. in Semper's Reisen, Heft xvi. 2, pp. 815-7.

Three specimens, labelled "Salomon." They are all much distorted and rolled up into balls. The length is about $40 \mathrm{~mm}$. and the breadth about $25 \mathrm{~mm}$. Two of them are pure white, but seem to have faint spots under the skin. The third is mottled with pale purplish grey. The dorsal surface is much puckered in all specimens, but apparently the ridges which it now bears are not natural. The rhinophore-sheaths are entirely closed and appear as low mounds. The branchiæ are six in number and tripinnate; the branchial pocket is six-toothed. The hard, rough dorsal surface is covered with small spiculous papillæ set not very close together. The dorsal integuments are crammed with short spicules, either straight or bent. The wide mantlemargin measures $8-9 \mathbf{m m}$. The foot is short and narrow.

There is no labial armature.

The formulæ of two radulas examined are: (a) $21 \times 35.0$. 35 and (b) $28 \times 40.0$. 40 . The teeth are simply hamate. Those in the middle of the half-rows are large. The six or eight nearest to the rhachis on either side are smaller, with long bases which bear a projection or denticle. The innermost often cross over the rhachis. The outermost are smaller but not degraded. The genitalia are small and undeveloped; the orifices are invisible externally and no armature was found. 
9. Thordisa crosslandii, Eliot, 1903. (Plate 25. figs. 1, 2.)

$=$ Diaulula gigantea, Bergh, 1905.

$?=$ Doris nubilosa, Pease, 1872.

See Eliot, in Proc. Zool. Soc. 1906, pp. 656-7, for the identity of these species.

One fine specimen from Coetivy. Not dissected. It is somewhat bent, but about $1.2 \mathrm{~mm}$. long and $9 \mathrm{~mm}$. broad. The tips of the rhinophores are dark. The branchiæ are six and greyish. The back is covered with thick-set, soft, conical papillæ. The animal was not dissected, in order to preserve it, as being a remarkably fine specimen. I have no doubt that it is the same species as that found by me at Zanzibar and described as Thordisa crosslandii.

The Doris nubilosa of Pease (American Journal of Conchology, vii. p. 13, 1872) is perhaps the same as this form, but the identity is hardly demonstrable.

\section{DISCODORIS.}

The lists of this genus contain some species in duplicate under two names and also several doubtful species, both old and new. The examination of a considerable number of type specimens, those of Abraham in the British Museum, those in the collection of the Challenger (British Museum) and of Semper (Copenhagen Museum), and those of Alder and Hancock (Hancock Museum at Newcastle-on-Tyne), enables me, I think, to simplify somewhat the nomenclature.

Bergh's Disc. concinniformis and Disc. morphea are identical with the older D.concinna and $D$. fragilis of $A$. \& H. The D. pardalis of those authors is almost certainly identical with some later species, perhaps with $D$. cebuensis, but without a better knowledge of the living animals no identity can be proved. Among Bergh's own species an examination of fresh material has convinced me that $D$. meta is merely a variety of $D$. boholiensis, and it is also possible that $D$. cebuensis and $D$. modesta are varieties of one form.

Among Abraham's species the only certain Discodoris is D. labifera, redescribed by Mr. Farran. D. vestita is a Diaulula. D. raripilosa is perhaps Bergh's Hoplodoris desmoparypha. D. stragula is not, in my opinion, identifiable.

The forms from the Atlantic and Mediterranean, where the genus seems well represented, are all fully described (though information about the living animals is scanty), but often present some characters at variance with the definition of the genus. I have marked them with a query in the list given below. But I have omitted from this list four species, noticed by Bergh in his description of the Siboga Collection, viz.: $D$. liturata, D. lutescens, D. versicolor, and D. siboge. As the author admits, all these forms are extremely doubtful for one reason or another and many of them have features (e.g., the teeth of Disc. lutescens) which are quite anomalous in this genus. They should not, I venture to think, be included in it without renewed examination.

An examination of the type specimens shows that $D$. notha (West Indies) and D. concinna (Indo-Pacific) are very nearly allied, but, considering the difference of habitat, I hesitate to identify them without further evidence. 
The Doris ellioti of Alder \& Hancock is not a Discodoris but a Platydoris (as is clearly shown by the buccal parts and genitalia of the type specimen), and therefore the Discodoris described by Bergh in his account of the Siboga Collection, p. 102, cannot bear this specific name.

The genus as at present known may be tabulated as follows:-

1. Discodoris boholiensis, B. Var. meta, B.

2. D. pardalis, A. \& H.

(3. D. cebuensis, $\mathrm{B}$.

4. D. modesta, B.

5. D. fragilis, A. \& H. $=D$. morphea, $\mathrm{B}$.

6. D. amboinensis, B.

7. D. carulescens, B. This form has a remarkable structure of the hermaphrodite gland, which may be of generic importance.

8. D. schmeltziana, B. Though this form is elaborately described, it does not seem to have any very certain characters except the colour.
9. D. labifera (Abraham).

10. D. concinna, A. \& H. $=D$. concinniformis, $\mathrm{B}$.

(Nos. 1-10 are all from the IndoPacific.)

11. D. notha, B. West Indies.

12. D. muta, B. Atl.

13. D. indecora, B. Med. \& Atl.

14. D. edwardsii, Vays. Atl., Morocco.

15. D. tristis, B. Atl.

16. D.? erubescens, B. Trieste.

17. D. branneri, MacF. Brazil.

18. D. ? vonjheringi, MacF. Brazil.

19. D. heathi, MacF. California.

20. D.? dubia, B. Smooth. Tasmania.

21. D.? egena, B. Smooth. Tasmania.

10. Discodoris fragilis (A. \& H.), 1864.

$=$ Discodoris morphaa, Bergh, 1877.

See Alder \& Hancock, in Trans. Zool. Soc. vol. v. 1864, pp. 118-9; and Bergh on D. morphaa, Malac. Untersuch. in Semper's Reisen, Heft xii. 1877, pp. 536-9, and Challenger Report on Nudibranchiata, 1888, pp. 93-98.

One large specimen labelled "Lagoon, Diego." It is much bent, but about $90 \mathrm{~mm}$. long and $70 \mathrm{~mm}$. broad. The curious autotomy (which gave rise to the specific name) was beginning when the creature was preserved and a cleft is visible nearly all round the dorsal surface of the body, which would have resulted in the whole mantle-margin being thrown off. I have seen the living animal perform this operation and crawl away, leaving the discarded margin as a complete ring.

The epidermis detaches itself with great ease and has disappeared from most parts of the dorsal surface. Such fragments as remain are covered with minute, blunt, whitish tubercles and mottled with various shades of grey. The anterior margin of the foot is deeply grooved and the upper lamina is notched, although Alder and Hancock state the contrary. The oral tentacles are cylindrical and pointed. The rhinophores have white tips and project from slightly raised sheaths. The branchial pocket is obscurely 6-lobed. The branchiæ are six in number, strong and ample, set in a circle open behind. They are grey but lighter at the tips.

The integuments are soft and slimy, but contain spicules as described by Alder and Hancock. The membrane which lines the body-cavity has a pinkish tinge. The labial armature consists of two triangular or hatchet-shaped plates which are composed of 
brownish rods. The radula consists of 56 rows, each containing from 90 to 100 teeth on either side of the rhachis. The teeth are of the ordinary hamate shape: the innermost have low shafts and long bases which are prolonged a little in front of the point where the shaft rises; the outermost are erect and spike-like.

The stomach lies outside the liver and its inner walls bear numerous moss-like folds near the exit of the intestine. This latter, after issuing from the stomach, makes a bend under the liver-mass and comes up again on the same side. The blood-gland is double and olive-coloured. The ampalla of the hermaphrodite gland is thick and coiled. The prostate is large and distinct, partly greenish and partly pinkish. The spermatotheca is large and green. The spermatocyst is small.

Alder and Hancock's D. fragilis has been neglected and the name has not been used in describing recent specimens. If I had only the evidence of the present specimen, which has suffered from self-mutilation and is otherwise poorly preserved, I should hesitate to revive the species. But I have also examined fresh specimens from Ceylon and the type specimens preserved in the collections of the Challenger and of Semper under the name $D$. morphea. I have no doubt that the $D$. morphaa of the Challenger Collection is $D$. fragilis, for it agrees in anatomy with the specimens received from Ceylon and also in external appearance, except that it has lost its colour. These Ceylon specimens agree with Alder and Hancock's descriptions in all points except that the upper lamina of the foot-groove is notched in the middle*.

Bergh himself has pointed out certain differences between the Challenger specimen of D. morphaa and that in Semper's Collection, and I feel less certain that this latter is identical with D. fragilis. But, on the whole, I think Bergh is right in regarding the two forms as varieties of one species.

The remarkable powers of self-amputation possessed by $D$. fragilis are also exhibited by a species of Gena (probably G. levis) which is common in the Indo-Pacific. The present collection contains some of the tails of this animal which were doubtless mistaken for nudibranchs. The mistake is very natural, as I can testify, for the tails continue to adhere and possess some power of movement after they have been thrown off. I once spent some time in examining them in the living state (if such an expression can be used) at Zanzibar and had difficulty in persuading myself that they were not complete nudibranchs. It would seem that Gena throws off its tail not only when it is attacked by some enemy, but whenever it feels uncomfortable. I have kept numerous specimens in confinement and have invariably found that they threw off their tails in a few hours.

\section{Discodoris modesta, Bergh.}

Bergh, Mal. Unters. in Semper's Reisen, Heft xii. pp. 534-6.

One specimen from Coetivy.

Length $35 \mathrm{~mm}$., breadth across back 20, width of mantle-brim about 7 . Dorsal

* The ends of the divided lamina overlap, so that the incisian is not conspicuous. 
surface thickly covered with small papillæ. Ground-colour white, but thickly mottled with various shades of brown. These mottlings are concentrated in places and form twelve irregular nearly black spots. On the underside of the mantle are large purplish spots, and on the foot are smaller confluent ones. The oral tentacles are cylindrical. The sheaths of the rhinophores are completely closed and form moderately prominent mounds. The branchiæ are six, tripinnate, and mottled brown.

The labial armature consists of two triangular plates: the top end is moderately broad, the lower end pointed. They are formed of small rods, not hooked or cleft. The teeth are all simply hamate, and the formula of the radula is $26 \times$ about 45.0 . 45 .

$D$. modesta is nearly allied to $D$. cebuensis, and perhaps merely a darker variety of it. But there are some small differences in the buccal parts.

\section{Discodoris cebuensis, Bergh.}

Bergh, Mal. Unters. in Semper's Reisen, Heft xii. p. 526.

Two specimens from Coetivy.

Both are of a pale colour and have extremely wide mantle-margins. The larger, which is $39.5 \mathrm{~mm}$. long, $20 \mathrm{~mm}$. broad, with a mantle-margin measuring $8 \mathrm{~mm}$. at the sides and $11 \mathrm{~mm}$. at the head and tail, is almost pure white, with traces of brown colour in the middle of the back. The other, which is similarly proportioned, but only $15 \mathrm{~mm}$. long, is bluish white with many spots of various shades of purple, which are themselves formed by an aggregate of smaller spots. In both there are a few brownish flecks on the undersides.

The animals are flat and soft. The integuments are spiculous, and the dorsal surface is covered with small spiculous tubercles.

The labial armature consists of two plates set so close together that they almost form a circular band composed of small rods. The formulæ of the two radulæ are respectively $20 \times 30.0 .30$ and $17 \times 20.0 .20$. The teeth are large and hamate. Those nearest to the rhachis have a small denticle at the base of the shaft. The outermost are small and erect.

These specimens seem to represent a light variety of D. cebuensis. I have compared them with the type deposited in the Copenhagen Museum.

\section{Kentrodoris rubescens, Bergh.}

Bergh, Mal. Unters. in Semper's Reisen, Heft x. p. 411.

One specimen labelled "Salomon." It is $67 \mathrm{~mm}$. long and $22 \mathrm{~mm}$. broad. The skin is quite soft and smooth to the touch, but under a lens is seen to be covered with very minute papillæ. The ground-colour of the dorsal surface is greenish grey, still showing a tinge of pink, which was stronger when the specimen was first received. Over this pinkish ground are scattered a considerable number of short lines about $4 \mathrm{~mm}$. in length. They are more distinct and thicker on the head and the tail-end of the mantle, where they even form spots. There are a fow of them on the underside of the mantle and on the sole of the foot, which shows traces of having been pink. 
The oral tentacles are long and digitate. The upper margin of the foot is grooved, and the upper lamina is expanded into very ample lappets with a considerable space between them, as shown in Bergh's figure ( $l$. c. plate xlix. fig. 14). The foot and back extend for some distance behind the branchix, but there is no separate tail whatever. The branchiæ are seven and very large. They rise out of a wide flexible cup like a sleeve; the margin is soft and undulated but not crenulate. The rhinophores are very large and thick; their sheaths are like the branchial pocket on a smaller scale.

The radula has a maximum formula of $50 \times 35.0 .35$. The teeth are tall and erect, with rather blunt tips. The teeth nearest the rhachis are thinner than the others, and bear a denticle or projection on the base.

The specimen was not further dissected, in order to preserve its appearance. It is undoubtedly $\boldsymbol{K}$. rubescens, Bergh, and the animal figured by me under that name, l.c.

\section{PLATYDORIS.}

This genus is in much the same condition as Discodoris, and it may be well to review briefly the list of species.

Bergh has shown that $P l$. punctuolata and $P l$. variolata (d'Orbigny) are really referable to Anisodoris. The two species described by the same author from the Canaries have not been seen since. D. canariensis can hardly be a Platydoris, for its back is said to be soft and velvety; but Pl. punctata (d'Orbigny), though doubtful, may perhaps be allowed to stand with a query. $P l$. incerta, Eliot, is an immature form, and may be neglected. Pl. papillata, Eliot, is almost certainly Hoplodoris desmoparypha, B. There is some discrepancy in the accounts of the labial armature, and also some doubt as to whether the form should be regarded as a Platydoris or the type of a new genus. Quoy and Gaimard's Doris sordida is, perhaps, the same animal, but it is difficult to prove the identity *. Farran's Pl. ? spinulosa should not, I think, be referred to this genus.

I have examined Abraham's original specimens, and think $D$. murrea unidentifiable; D. hepatica is probably a Platydoris but looks discoloured, and it seems unsafe to found a species on a single dubious specimen. But Platydoris tabulata, of which I have dissected the type specimen, is a valid species allied to Bergh's Pl. variegata, and perhaps identical with it, in spite of some variations in colour and other details. $P l$. inframaculata and Pl.speciosa are allied to one another and to Alder and Hancock's Pl. ellioti. It is not impossible that all may be rarieties of one species. But at present I do not think this demonstrable. An examination of a large series of Japanese specimens which I have made indicates that Abraham's Pl. speciosa was immature. The full-grown animal is 15 centimetres long or more. The back is covered with dark mottlings of many shades of brown and purple, which vary greatly in different specimens. The underside is deep clear yellow with bold black blotches. Pl. formosa 
(A. \& H.) is perhaps a colour-variety of this species in which the dark brown and black are replaced by red, but provisionally it is better to keep it separate.

After an examination of the type specimens I have no doubt that Pl. eurychlamys, B., and $P l$. coriacea, Abraham, are the same. I have compared with them specimens from East Africa which I identify with the D. scabra of Quoy and Gaimard. Though the description given by these authors deals with the external features only, it contains so many details that I have no doubt of the identification. Cuvier's D. scabra is unrecognizable from his description, but Quoy and Gaimard may have had access to his specimens. At any rate, their interpretation of $D$. scabra would seem to be authoritative. D. solea, Cuvier, is also unrecognizable, and it is not even certain that it is a Platydoris, for Cuvier seems to contrast its texture with D. scaber.

Bergh admits (Siboga Exp. Opisth. p. 136) that his $P l$. arrogans and $P l$. cruenta (Q. \& G.) are synonyms. It is possible that $P l$. striata, $P l$ flammulata, and $P l$. sanguinea are all varieties of the same species. The constant feature in the colourpattern is that the dorsal surface bears numerous fine lines which seem to be engraved on it. Three variations of this scheme occur: (a) in Pl. striata, there is no red, only a yellowish ground bearing darker lines; (b) in $P l$. cruenta and $P l$. flammulata the pattern is similar but splashed with red; (c) in Pl. sanguinea the red spreads all over the dorsal surface, but a black reticulate pattern is seen below it. But at present the differences reported to exist in the armature of the genitalia make it difficult to unite the species. With regard to these differences, ampler data are required before we can know whether a particular form of spine or scale is of specific value. The real characteristic of the genus is that the efferent ducts of the genitalia are lined with an unusually thick cuticle, which is thrown up into ridges and prominences. These latter generally form (in the male branch) distinct discs bearing spines, but it is not impossible that in some individuals these discs and spines may be imperfectly developed and appear merely as lumps. But only a few specimens of each form have been dissected.

The genus as at present known may be tabulated as follows :-

1. Pl. scabra (Cuv. and Q. \& G.).

$$
\begin{aligned}
= & P l . \text { coriacea (Abraham). } \\
= & P l . \text { eurychlamys, } \mathrm{B} . \\
& P l . \text { vicina, B., is probably a } \\
& \text { variety. }
\end{aligned}
$$

(2. Pl. cruenta (Q. \& G.).

$$
=\text { Pl. arrogans, } \mathrm{B} \text {. }
$$

3. Pl. striata (Kelaart).

4. Pl. sanguinea, $\mathrm{B}$.

5. Pl. flammulata, B.

6. Pl. formosa (A. \& H.).

7. Pl. ellivti (A. \& H.).

8. Pl. inframaculata (Abraham).

9. Pl. speciosa (Abraham).
10. Pl. ? variegata, B.

11. Pl. ? tabulata (Abraham).

12. Pl.pulchra, Eliot.

13. Pl. herdmani, Farran.

All the above are from the Indo-Pacific.

14. Pl.punctatella, B. W. Coast of S. America.

15. Pl. argo, L. Atlantic and perhaps also Indo-Pacific.

16. Pl. philippii. Med.

17. Pl. ? punctata, d'Orb. Canary Islands. 18. Pl. angustipes (Mörch). W. Indies. 


\section{Platydoris tabulata (Abraham).}

P. S. Abraham, Revision of the Anthobranchiate Nudibr. Mollusca, Proc. Zool. Soc. 1877, p. 249.

One specimen, without notes as to locality. It is small compared with those in other collections, and perhaps not full-grown. Length $43 \mathrm{~mm}$., breadth 29 . Foot only $26 \mathrm{~mm}$. long and 5-7 mm. wide. Mantle-margin very ample : 10-12 mm. wide. The whole aninial is very flat and hard, and the back is covered with numerous very minute papillæ. The ground-colour of both the upper and lower surface is yellowish white. Much of the dorsal area is covered with fine purple dots, but there are considerable bare spaces in the middle and elsewhere. The absence of dots on them may, however, be due to abrasion. On the underside of the mantle is a band of purple dots round the foot. The rhinophores are dark violet-grey. The branchiæ are six and tripinnate: their main axes are reddish below ; the prefoliations are violet-grey ; in all parts there are numerous dark dots. The pocket is indistinctly six-toothed. 'The oral tentacles are large and grooved.

The labial cuticle bears an armature of rods, which though of a faint grey and not conspicuous is yet distinct. It consists of two longish plates, which are thicker and darker at the ends where they are nearest each other. The maximum formula of the radula is $30 \times 80.0 .80$. The outermost tooth has no hook, but bears irregular denticles on the apex and also occasionally on the side. The outermost tooth but one bears a hook which is reduced but still clear, and below it a few irregular denticles. The remaining teeth are hamate and rather slender.

The cesophagus is rather large. The stomach lies in a cleft of the liver, but is not enclosed by it. Its walls are thin, not muscular, and slightly laminated internally. The liver is brown and traversed internally by unusually large tubes and passages. It is covered by a thick yellowish layer composed of the hermaphrodite gland.

The blood-gland is purplish grey and composed of two parts, of which the anterior is larger. The ganglia of the central nervous system are yellowish and fairly distinct. The common commissure is very distinct. The eyes are set on short stalks.

The ampulla of the hermaphrodite gland forms two or three thick convolutions. The albumen and mucus glands are of moderate size. The spermatotheca is round, brown, and full of spermatozoa. The spermatocyst is elongate and stalked; it rises close to the spermatotheca and is bent on itself, so as to appear double. The prostate is large and globular. Attached to the bag which contains the penis is a pear-shaped flocculent gland with a longish duct. The lower part of the vas deferens (and it would appear the glans penis too) bears strong, jagged, pinkish folds, which rise into bent spines of a pinkish colour set in six rows. Higher up there are no spines but only jagged colourless folds. The vagina is lined with a thick red cuticle bearing folds on which are knobs and prominences. Though the whole armature is very similar to that of the male branch, there are no true spines in it.

This form is nearly allied to Bergh's $P l$. variegata, which also possesses the anomalous character of a labial armature and a somewhat similar radula. The two may be varieties 
of a single species (in which case the name tabulata of 1877 has priority over variegata of 1880), but there are many differences of detail. The coloration of the dorsal surface is not strikingly similar: $P l$. tabulata has no lines on the foot; its oral tentacles are large and grooved, whereas those of $P l$. variegata are small and digitate.

A drawing of the living Pl. tabulata made in Japan represents it as brownish yellow, the medio-dorsal area being darker than the marginal regions. The margin itself is lighter and there are five irregular whitish spots on various parts of the back. The whole of the dorsal surface, whatever its colour, is thickly spotted with minute dark purplish dots. The branchiæ are greyish white; the rhinophores have yellowish stems and violet-grey perfoliations. The mantle-edge is much undulated and wrinkled.

\section{Platydoris herdmani, Farran.}

Farran, Opisthobranchiate Mollusca in Herdman, Ceylon Pearl Oyster Reports, pp. 337-8.

Two specimens from Amirante, similar in appearance and size : about $45 \mathrm{~mm}$. long and $30 \mathrm{~mm}$. broad.

The colour is yellowish brown with mottlings and spots of darker brown, which seem to lie underneath the skin. On the under surface of the mantle are numerous purplish dots. The dorsal surface is softer than is usual in Platydoris, but is minutely granulated. The branchiæ are small and six in number. The pocket is completely closed in both specimens, but its natural shape is probably stellate.

The mouth-parts are on the whole as described by Farran, though the precise sequence of teeth mentioned by him is not always maintained. The formula of the radula is about $45 \times 70.0$. 70. The majority of the teeth are stout, simply hamate, and often with blunt tips, but at the outer end of the rows there occur more or less degraded teeth of three types: (1) hamate teeth bearing a few irregular jags or denticles below the principal hook; (2) teeth with pectinate hair-like denticles, similar to those found in Thordisa; (3) flat plate-like teeth without any cusp or denticles.

The vas deferens is thick and broad. It is clothed with a hard yellow cuticle on which are set two rows of scales bearing slightly bent looks. The vaginal hooks mentioned by Farran were not found, but the external appearance of the species is so distinct that there can be no doubt of its identity.

\section{Asteronotus hemprichii, Ehrenberg.}

See Ehrenberg, Symbolæ Physicæ, Animalia evertebrata, 1831, and Eliot, in Proc. Zool. Soc. 1903, vol. ii. pp. 384-5.

One relatively small specimen from Egmont: length $48 \mathrm{~mm}$., breadth $36 \mathrm{~mm}$. The ground-colour is greenish grey composed of a multitude of minute dots. The tubercles are lighter. The consistency and external features are as usual in the genus. On the underside of the mantle is a broad chocolate band extending nearly all round the foot and interrupted only at the tail end. It contains several lighter areas.

Through the courtesy of the authorities of the Copenhagen Museum, I have been able to examine their specimens of $A$. hemprichii, Ehrenberg, and $A$. cespitosus (van Hasselt), 
identified by Bergh. I am of opinion that they both represent varieties of one species which is very common on the east coast of Africa.

17. Chromodoris quadricolor, Rüppell \& Leuckart, var.

See Rüppell and Leuckart, Neue Wirbellose Thiere, 1828, p. 31 ; Bergh, Siboga Expeditie, 1905, p. 143 and references there quoted. For Chr. lineata and Chr. magnifica see Eliot, Proc. Zool. Soc. 1904, vol. i. pp. 396-398.

One specimen labelled “Passe Honareau, Aldabra." As preserved, it is $25 \mathrm{~mm}$. long, $10 \mathrm{~mm}$. higb, and $12 \mathrm{~mm}$. broad. The mantle-margin is about $3 \mathrm{~mm}$. wide in most places, but rather wider before and behind, where it covers the head and foot. The body and foot are somewhat bent, and there can be little doubt that, like many other Chromodorids, the animal is capable of assuming another shape in which the body is lower and flatter, the mantle-margin broader, and the foot longer.

The colours are black, greyish or yellowish white, and faded orange distributed very much as depicted in Quoy and Gaimard's figure of Doris magnifica. The mantle-edge is marked by a white border; next to this, on the lower as well as on the upper side, is a broad ( $3-4 \mathrm{~mm}$.) orange band, and next to the orange band a black band, continuous but of irregular width. The remainder of the dorsal surface is whitish, but traversed by broad, distinct, longitudinal, black lines. At any given point between the rhinophores and branchiæ there are about six of these lines, exclusive of the black band. The median line runs straight from the branchiæ to the anterior mantle-margin, but the others are more or less branched and interrupted. Three of them pass between the rhinophores and two terminate just behind the rhinophores. The rhinophores and branchiæ are orange: there are orange borders round their pockets, round the foot, and round the genital orifices. The sole of the foot is pale orange, but the sides of the foot and body and the upper surface of the tail are, like the back, whitish but traversed by longitudinal black lines, more regular than the dorsal pattern, but in a few places branched or interrupted. There are five on the right side, four on the left, besides the circular black band which (just as on the dorsal surface) adjoins the orange border.

The surface is smooth and both the integuments and internal membranes are tough and hard to cut. The margins of the rhinophorial pockets are slightly raised, but that of the branchial pocket not at all. The anterior margin of the foot is thickened and slightly grooved. The tentacles, which seem to be invaginable, are represented by round knobs. The branchiæe are 15, but possibly one or more of them should be regarded as accessory plumes or branches. They are roughly pyramidal in shape and of different sizes, set in a circle open behind, the plumes nearer to the opening being smaller than the others.

The intestines are of a yellowish brown. The buccal mass is large. The labial armature is yellowish and has the appearance of a ring, but consists of two semicircular plates almost in contact. The elements are somewhat variable in shape and size. The majority are rods, swollen near the distal end, generally bent and generally bifid; but near the edges of the plate they are smaller and sometimes roughly triangular. The radula is 
dark brown in front; yellow behind. There are about 80 rows, of which the longest contain 90-100 teeth on either side of the rhachis, which bears slight triangular thickenings. The teeth are strong, erect, and hamate, not bitid but bearing as a rule 6-9 denticles rather low down on the shaft. The denticles are short, thick, and not conspicuous, though when the teeth are in a favourable position they can be seen quite clearly. As in most Chromodorids, the innermost teeth are broad and denticulate on both sides; the outer teeth are straighter, less hamate than the others, and bear denticles on or near the tip.

The other internal organs appear to be as usual in the genus. The œsophagus runs straight into the liver without any dilatation, and the hepatic cavity acts as a stomach. Undigested food was found in two chambers within the hepatic mass.

There appear to be two variable species of Chromodoris which in certain varieties present a similar external appearance. One of these may be called Chromodoris quadricolor (Rüppell), which was admitted by Bergh to be the same as his Chr. elizabethina and Chr. anne. In the typical form this species is characterized externally by stripes of four colours-white, orange (red or yellow), dark blue, and light blue. But the dark and light blue may both become black and the relative quantity of dark and light colour may vary, so that some specimens appear to be dark animals with light stripes, others to bear dark stripes on a light ground. In all these varieties the ralula seems to be similar. It consists of rather erect teeth, not bifid at the tips, and bearing about eight denticles.

The other species may be provisionally called Chr. lineata (Souleyet, 1852) and is probably identical with Chr. magnifica, Q. \& G. (1832), and Chr. hilaris, Bergh. These forms are yellowish, with orange-coloured branchiæ and rhinophores and violet stripes on the back and sides. The teeth of the radula are bifid (so far as is known) and bear about four small denticles below the bifurcation.

It will be seen that if the stripes of Chr. quadricolor are multiplied, it becomes similar both in pattern and coloration to Chr. lineata or Chr. magnifica. This has happened in the specimen here examined, but as it has teeth of the shape found in the typical form of Chr. quadricolor, I think it should be referred to that species.

It may be asked if the teeth are not as variable as the coloration. It may be so, but the specimens of Chr. quadricolor hitherto examined, though differing in external appearance, present the same type of tooth. It is possible that Chr. quadricolor and Chr. linearis may both prove to be varieties of one widespread and very variable species, but at present I think nothing would be gained by ignoring the differences which seem to separate them. Though the specific name magnifica has priority, it is better not to use it until the character of the radula has been ascertained in specimens indubitably referable to the species. Both the present specimen and the one from Zanzibar described by me (l. c.) resemble Quoy and Gaimard's plate, but their radulæ are not the same 
18. Ceratosoma ornatum, Bergh.

See Bergh, Mal. Unt. in Semper's Reisen, Heft xvii. pp. 946-7, and Eliot on C.cornigerum in Proc. Zool. Soc. 1904, vol. i. pp. 401-2.

One specimen from Seychelles, 37 fathoms. As preserved it is $37 \mathrm{~mm}$. long and $11 \mathrm{~mm}$. broad across the back at the widest part. The colour is semi-transparent yellowish white, thickly spotted with opaque white. Round the frontal and dorsal margins and also round the margin of the foot is a row of faded rose-coloured spots. The prominence behind the branchire is bordered with a continuous line of the same colour. The shape is as usual. There are two wavy and not very decided lobes on either side of the mantlemargin and behind the branchiæ a well-developed process $6 \mathrm{~mm}$. long.

I think this is the C. ornatum of Bergh, but doubt if it is more than a colour-variety of C. cornigerum, Adams.

19. Spharodoris levis, Bergh.

See Bergh, Mal. Unters. in Semper's Reisen, Heft xvii. p. 924 (1890), and Eliot, in Proc. Zool. Soc. 1904, vol. i. pp. 403-4.

Two specimens from Coetivy, about the same size $(25 \mathrm{~mm}$. long, $22 \mathrm{~mm}$. broad) and colour. They are brownish olive with various faint mottlings. There is a conspicuous circular area round the branchial pocket, lighter and slightly depressed. In both specimens there are obscure traces of dorsal ridges and two pits arranged symmetrically one on each side between the branchiæ and rhinophores.

These specimens are I, think, referable to the form described by Bergh and myself under the name of Sph. levis. The indications of ridges which they present suggest that they may be immature and subsequently develop a more uneven and tuberculate dorsal surface. It is hard to believe, however, that they are the young of Sph. punctata or papillata. These two species (of which I have examined the type specimens) perhaps represent different ages of the same animal, but both seem to be different from the relatively smooth species.

It is possible, but hardly demonstrable, that this animal is the Actinocyclus verrucosus of Ehrenberg.

\section{ORODORIS.}

This genus, recorded only from the Indo-Pacific, comprises animals of a considerable size with ridged and tuberculate backs. The large tubercles bear subsidiary knobs and are irregular in shape. They are arranged so as to form a median ridge with side ridges running to the mantle-margin. The branchiæ are tripinnate. A labial armature is present. The radula is large; there is no central tooth; at least some of the lateral teeth are finely denticulate. There is no armature on the genitalia. The affinities of the genus are uncertain. In many. ways it is allied to Asteronotus (especially $O$. striata), but the buccal parts are different. Two species are known:-

1. O. miamirana, Bergh. Philippines, Tahiti, New Britain, Zanzibar.

2. O. striata, Eliot. Zanzibar, Praslin. 
An examination of the original specimens has convinced me that the animal described by me as Fracassa tuberculosa (Proc. Zool. Soc. 1903, vol. ii. p. 371) is really O. miamirana. The outer teeth as well as the inner are often, if not always, denticulate in this species. The genus Fracassa, Bergh, is represented only by one specimen in the Copenhagen Museum. Its appearance may have altered with age, but in its present condition it hardly supports Bergh's statement that "Die Fracassen stimmen im Ausseren fast mit den Phlegmodoriden überein." As the specimen stands, it does not seem to me necessary to separate it generically from Discodoris and the genus Fracassa requires confirmation.

\section{Orodoris striata, Eliot.}

Eliot, in Proc. Zool. Soc. 1904, vol, ii. p. 269.

Four specimens, labelled "Praslin, reef." They are about $100 \mathrm{~mm}$. long and $80 \mathrm{~mm}$. broad. When first received they showed considerable traces of light green and pink arranged in thin stripes, but this coloration subsequently vanished.

Though the specimens are large and in some ways well preserved, yet they have clearly all been distorted by the preserving fluid in different ways, and it is not easy to deduce the original shape. Probably there was a central ridge bearing three large tubercles (as much as $12 \mathrm{~mm}$. high and $10 \mathrm{~mm}$. broad at the base), and on either side of this ridge two or three rows of tubercles. There is also at least one large tubercle behind the branchiæ, and the whole dorsal surface, including the tubercles, is covered with low ridges, often broken up into short lines. The general external characters, as far as they can be determined, are much like those described by me (l.c.). The mantle-margin is thick, fleshy, and very broad. The foot is narrow. The anterior part of the foot and the mouth are swollen and distorted in all specimens, but apparently a ridge runs from the mouth on either side downwards to the foot. The branchiæe are seven or eight, and very large. The anterior median plume is connected with the anal papilla by a lamina. The margin of the pocket is somewhat raised and bears irregular indistinct lobes.

The labial armature is a mass of bright yellow bent rods. In the specimen dissected the radula consisted of 130 rows, with about 150 teeth on either side of the rhachis. Until carefully examined the teeth appear to be simply hamate, but closer scrutiny shows that those next to the rhachis bear two denticles on the inner and three on the outer side. Of the remaining teeth, the first twenty or so have a ridge on the outer side which bears a varying number (generally about 10) of irregular denticles. The remaining teeth appear to be smooth.

I think that these specimens are referable to Orodoris striata, recorded from Zanzibar, and that the species is distinct from $O$. miamirana.

\section{Miamira magnifica, sp. nov. (Plate 25. figs. 10, 11.)}

See accounts of $M$. nobilis or sinuata by Bergh in Jour. Mus. Godeffroy, Heft viii. 1875, pp. 53-63 ; id. in Semper's Reisen, vi. ii. 1904; id. Notes from the Leyden Museum, 1887, p. 309, pl. vi. fig. 10 ; and by Eliot in Proc. Zool. Soc. 1904, vol. i. p. 405.

One specimen from Seychelles, 34 fathoms. 
Length $58 \mathrm{~mm}$; ; breadth $15 \mathrm{~mm}$; height, exclusive of tubercles, $18 \mathrm{~mm}$.

The coloration is complicated. It may be described as a white ground ${ }^{*}$ covered with a reticulation which is in parts green and in parts purple. The green pigment is light but not bright, and often tinges the white areas in its vicinity. In many places the green is replaced by a rather bright purple, especially on the oral veil, the side-lobes, the dorsal tubercles, and the sides of the body below the mantle-margin. The white areas often bear opaque white spots. Much of the colouring disappeared when the specimen was eviscerated.

The whole animal, sides as well as back, is covered with low smooth pustules, as much as $3 \mathrm{~mm}$. in diameter. Besides these there is a ridge running down the centre of the back, bearing a small prominence in front of the rhinophores, a rather larger one behind them, and a much larger one $(8 \mathrm{~mm}$. high) in the middle of the back in front of the branchiæ. Behind the branchiæ the ridge is not continued, but there are two prominences of considerable size. Very indistinct ridges seem to run from the central ridge to the side-lappets, and above each lappet is a rather large tubercle. The oral veil is distinct, but not ample, and not divided. It is continued on either side as a pallial margin, and passes behind the branchiæ. At this point there is a tubercle, but no prominence that could be called a caudal veil. The tail behind the pallial margin measures $12 \mathrm{~mm}$. The pallial margin bears on either side four lappets (with a fifth rudimentary one on the right) provided on the underside with transverse lamellæ. The rims of the rhinophorepockets are slightly raised, smootb, hard, and white. The branchial pocket is completely closed, but its edge appears to be similar. The rhinophores, which are completely retracted, are large and bright purple, but with yellowish-white tips and yellowish-white lines down the sides, making a vivid contrast of colours. The gills are completely retracted, ten or perhaps twelve in number, for it is difficult to distinguish branches and independent plumes. They are irregularly tripinnate and pinkish grey; but the rhachis inside is yellowish white, and, as in the rhinophores, makes a vivid contrast of colours.

The blood-gland is brownish and irregularly trilobed. The central nervous system is large, but difficult to extract from its capsule. The cerebral and pleural ganglia are united in a single mass, which is somewhat narrow and elongate. The pedal ganglia are distinctly separate from it. The eyes are small and black.

The buccal mass is large, and the anterior part is of a beautiful purple colour. The labial armature is a yellow band with a white edge. It is $4 \mathrm{~mm}$. broad and appears to be interrupted in the middle, but in reality this interval bears spines of the same kind as the rest, only colourless. They are hooks or bent rods, but not bifid. The radula is very large and has a formula of at least $112 \times 250.0 .250$. The teeth are small, simply hamate, and irregular in size, tall and short ones often standing side by side. The points are often blunt. The innermost are hard to see, but are apparently like the rest, only stout and with broad bases. The outermost are rather irregular in shape, but none of the teeth are denticulate.

The right salivary gland is a long band measuring $20 \mathrm{~mm}$; the left is only a quarter of the length. The osophagus is short, and after forming a slight dilatation enters the

* This description was taken from the preserved specimen some time after the coloured drawing was made. 
stomach, which is not large, but except at its hinder end free from the liver. Being white, it is clearly distinguished from the liver by its colour. The intestine is large and broad, and describes a wide bend in front of the liver. This latter is greenish, but most parts of it are covered by the yellowish hermaphrodite gland. The surface is deeply channelled. The ampulla of the hermaphrodite gland is long and coiled. The spermatotheca is greyish; the spermatocyst yellow. The vas deferens is long and coiled. The albumen and mucus glands form a small compact mass; the accessory gland described by Bergh was not found.

It is with some doubt that I register this form as a new species, though it in any case represents a well-marked colour-variety. It is very unlike the original specimens of M. sinuata (= nobilis) to look at, but when the points of difference are analysed they are found to concern chiefly the colour and the size of the lobes and tubercles. 'Ihe following divergences in structure may also be noticed:-

(1) In $M$. sinuata the frontal veil is trifid and (in the specimens $I$ have seen) narrow. In $M$. magnifica it is broad, semicircular, and entire.

(2) In $M$. magnifica the radula is much larger, though the animal is smaller.

(3) In $M$. sinuata the stomach is surrounded by the liver; in $M$. magnifica it lies almost entirely outside it.

These differences, taken in conjunction with the remarkable coloration, would no doubt be sufficient to constitute a species, provided they prove to be constant. Pending the examination of further material, the forms may be recognized as separate.

As far as can be judged from an examination of the original specimens, the plates of Miamira nobilis in Semper's 'Reisen' and the 'Journal of the Godeffroy Museum ' are very misleading. Van Hasselt's drawing, reproduced in Bergh's 'Notes from the Leyden Museum,' is better.

\section{Trevelyana alba, Bergh.}

Bergh, Mal. Uuters, in Semper's Reisen, Heft xi. p. 443.

One specimen, from Cargados Carajos, reef. It is stout, nearly cylindrical in the front and middle parts, but tapering towards the tail. The length is $38.5 \mathrm{~mm}$., the breadth $15 \mathrm{~mm}$., the height $16 \mathrm{~mm}$. The colour is whitish, with traces of yellow here and there in the creases. The branchiæe are 14, and of moderate size. They are set in a complete circle and are mostly bipinnate. On the tail behind them are four rather large low tubercles.

There is no labial armature. The radula is in a rather confused condition, but its formula seems to be about $30 \times 35.0$.35. The hermaphrodite gland consists of two separate roughly spherical portions.

Though this species is nearly allied to $T$. ceylonica, it is probably distinct. I have had an opportunity of examining several specimens of the latter from Ceylon, and find them all characterized externally by their large feathery branchiæ, measuring 8-9 $\mathrm{mm}$. in an animal only $30 \mathrm{~mm}$. long; whereas in $T$. alba the branchiæ are of moderate size. Further, T. ceylonica shows differences in the radula and the hermaphrodite gland. The 
latter does not consist of two spherical masses as here, but of two short thick coils spread over the top anterior part of the liver.

23. Plocamopherus indicus, Bergh.

Bergh, Mal. Unters, in Semper's Reisen, Heft xvii. pp. 954-958.

One specimen from Coetivy: $26 \mathrm{~mm}$. long, $9 \mathrm{~mm}$. high, and $7 \mathrm{~mm}$. broad. The colour is pale lemon-yellow, sprinkled everywhere with greyish spots. The oral veil is moderately large, but no appendages are visible; the caudal crest is also moderately large and jagged. The rhinophores are large and brown; the branchiæ three, small and brownish. Along the mantle-edge are traces of one or two retractile papillæ. On either side there is a single extrabranchial appendage, not branched, but, as preserved, globular in shape and pinkish brown.

The labial armature consists of two plates formed by fibrous-looking, pale yellow rods. Owing to the faintness of its colour this armature is not at all conspicuous, but it is in reality fairly large. The formula of the radula is $24 \times 12+11.0 .11+12$. The rhachis is broad and marked by transverse lines. The first eleven teeth are hamate; the twelve outermost are mere plates.

In spite of some differences in the colour and labial armature, I think this is a light variety of Bergh's Pl. indicus.

\section{Doridopsis nigra, Stimpson.}

See Eliot, in Proc. Zool. Soc. 1904, vol. ii. pp. 275-6.

This common species is represented in the collection by three specimens from Coetivy, two of moderate size and one small. They are not well preserved, but appear to belong to the greenish-black variety with indistinct borders and spots of a paler colour.

\section{Doridopsis sp.}

One small specimen about $10 \mathrm{~mm}$. long, from Coetivy, of a yellowish-white colour. 'It is perhaps an immature Doridopsis rubra. The buccal parts are as in that species.

\section{Phyllidia varicosa, Lam.}

One specimen from Salomon Atoll. It has the typical form and coloration. It is about $41 \mathrm{~mm}$. long, glossy black, with bluish ridges bearing yellow tubercles. The three central ridges are straight and distinct, only uniting near the end of the body.

Another specimen was obtained in Passe Dubois, Aldabra.

27. Phyllidiopsis carinata, sp. nov. (Plate 25. figs. 8, 9, 12.)

One specimen from Amirante E 16, 39 fathoms.

The length is $19 \mathrm{~mm}$., but as the specimen is bent this probably represents $22 \mathrm{~mm}$. or more. The breadth is $15 \mathrm{~mm}$.

Down the centre of the back runs a crest bearing tubercles, the tallest of which is about $3 \mathrm{~mm}$. high. The tubercles are conical and often compressed laterally, so that the SECOND SERIES.-ZOOLOGY, VOL. XIII. 
crest looks like a saw. Along either side of the central ridge runs another row of tubercles of nearly the same size; round the margin and also scattered among the large tubercles are a moderate number of small ones. The whole dorsal area, both the flat surface and the tubercles, as well as the underside of the mantle, is covered with minute roundish granulations.

The colour is yellowish white, but on the back are arranged five black areas, which make a striking contrast with the ground-colour. They are not placed symmetrically. One is in front, and two lie on each side but not opposite one another. Round each area is a ring of a brighter white than the rest of the ground-colour. The tubercles are tipped with the same bright white. The largest of the areas measures $8 \times 6 \mathrm{~mm}$., including the white ring. The tubercles extend over these areas as well as over the white surface, and preserve their white colour; but in this arrangement also the symmetry is imperfect. One black area contains three white tubercles, three contain one each in the centre, and one contains none at all. The rhinophore-pockets and anal papillæe are very hard to see. On the under surface of the mantle is a circuit of not very large white lamellæ, each about $3 \mathrm{~mm}$. long. The texture of the integuments is hard and spiculous.

A few minute pebbles were found with the animal in the bottle. It is probable that it lives on a pebbly bottom, where its black and white coloration, so conspicuous when it is isolated, harmonizes with the surroundings. At Naples I have observed that large and conspicuously mottled specimens of Tethys leporina become invisible when they settle among pebbles.

The integuments are full of short spicules arranged in bundles, and also of small hard granules of various shapes. Unfortunately the preserving fluid had not penetrated the hard skin, and the internal organs were shrivelled and dried. up. Near the mouth was found a bent tube, and it is probable that the buccal parts were of the type found in Doridopsis. A thin tube armed with rows of hooks was no doubt the vas deferens.

This form bears a remarkable superficial resemblance to Phyllidiopsis papilligera, Bergh, which was found in the Atlantic (Gulf of Mexico). This difference of habitat makes it improbable that the two animals are specifically the same, and they do not agree in details, though it must be confessed that if they had been found together the discrepancies could be explained away :-(1) P.papilligera is nearly circular $(12 \times 11 \mathrm{~mm}$.), whereas $P$. carinata is more elongate $(22 \times 15 \mathrm{~mm}$.). (2) Not only are the black areas much fewer in $P$. carinata (which is not in itself important), but they have a special border which, as preserved, appears bright white and is very noticeable. (3) In $P$. papilligera the dorsal papillæ have constricted bases and then swell out into an almost ovate outline; in this animal they have broad bases, a conical outline, blunt tips, and are often flattened laterally. (4) There are no ridges on the back of P.papilligera, but in $\boldsymbol{P}$. carinata a median crest or ridge bearing tubercles is a prominent feature.

28. Ceratophyllidia grisea, sp. nov. (Plate 25. figs. 3-7.)

Cf. Ceratophyllidia africana, Eliot, in Proc. Zool. Soc. 1903, vol. i. pp. 250-1.

One specimen from Coetivy. It is well preserved, but much bent; if straightened it 
would be about $30 \mathrm{~mm}$. long. The maximum breadth is $17.5 \mathrm{~mm}$. and the height $7 \mathrm{~mm}$. The shape is very flat. The general colour is a yellowish grey.

The back is studded with about 130 stalked processes, spherical or ovoid in shape. The stalks are small; at most they are $1 \mathrm{~mm}$. in length, but many are much shorter. The largest processes measure about $7 \times 5 \mathrm{~mm}$.; the smaller have a diameter of about one millimetre or less. The large ones are found only in the middle of the back. The little ones are set along the dorsal margin and are also found among the big ones. The upper half of each process is spotted with purplish brown: this colour is much more intense in the little ones, where it is nearly black, than in the larger ones, where it is only pale grey. The processes do not contain any diverticula or core of any kind and in section they show a uniform jelly-like texture. Under a microscope the coloured spots are seen to be minute, low tubercles.

The rhinophores are large, yellow, and laminated; they are completely retracted and the sheaths, which are closed, appear as inconspicuous mounds. The anal papilla is also inconspicuous; it is set very far back. The mantle-margin is ample (as much as $5 \mathrm{~mm}$. wide), thin, undulated, and soft. The margin of the foot is also expanded. When the animal is divested of its papillæ it looks more like a Doridopsis than a Plyllidia. The underside of the mantle bears some faint purplish spots and a row of not very welldeveloped yehow lamellæ; they are set close together and each is about $3 \mathrm{~mm}$. long. The integuments are full of spicules of very various shapes and sizes.

The intestines are much hardened and only the following points could be ascertained. The anterior part of the alimentary eanal is apparently arranged as in Doridopsis. There is no trace of a glandular mass as in Phyllidia. The cesophagus makes a bend near the central nervous system, which is much concentrated, the ganglia being fused into a continuous mass. The liver is greenish brown and not divided behind. The hermaphrodite gland is white and very large, forming a layer over the liver nearly $5 \mathrm{~mm}$. thick. The green spermatotheca and black spermatocyst are visible. The genitalia appear to have been much developed and to have squeezed the oesophagus and other organs against the dorsal integuments. The condition probably indicates the period immediately before eggs are laid.

This specimen belongs to the genus Ceratophyllidia, but is, I think, specifically distinct from C. africana, previously described by me. Superficially the appearance of the two species is quite different-C. africana being yellow with black globules on the back, distant about $2 \mathrm{~mm}$. from one another and allowing the ground-colour to be clearly seen; while C. grisea is grey of various shades and the globules touch one another, completely hiding the ground-colour, as will be seen from the drawing. In C. grisea (30 mm. long) the larger globules have a diameter of $7 \mathrm{~mm}$.; in C. africana (about $22 \mathrm{~mm}$. long) the largest do not exceed $2 \mathrm{~mm}$. in diameter, but the stalks are longer. Otherwise the differences are small, and of course it is possible that the use of different preserving fluids may have caused the globules to contract in one specimen or swell in the other; but provisionally I think it safer to register the two forms separately. 


\section{EXPLANATION OF PLATE 25.}

Fig. 1. Thordisa crosslandii: dorsal view, natural size.

Fig. 2. " " portion of back, enlarged, showing projections.

Fig. 3. Ceratophyllidia grisea : dorsal view.

Fig. 4. " " lateral view.

Fig. 5. " " section showing attachment of globules.

Fig. 6. " " side view of a globule, enlarged.

Fig. 7. " " plan of same, also enlarged.

Fig. 8. Phyllidiopsis carinata, sp. nov.: top view.

Fig. 9. " " black spot showing projection, enlarged.

Fig. 10. Miamira magnifica : top view.

Fig. 11. " " perspective view.

Fig. 12. Phyllidiopsis carinata : side view.

Fig. 13. Pteraeolidia annulata: one of the teeth. 


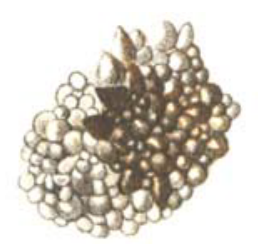

2.

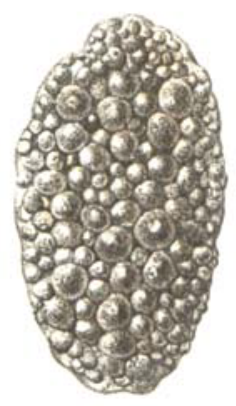

3.

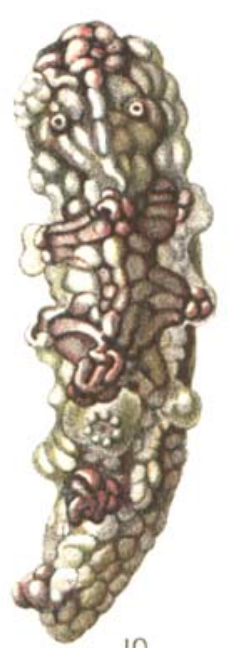

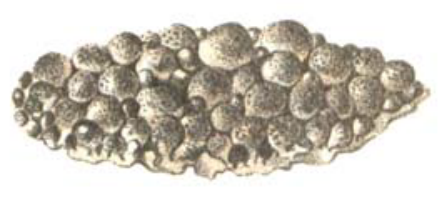

4.
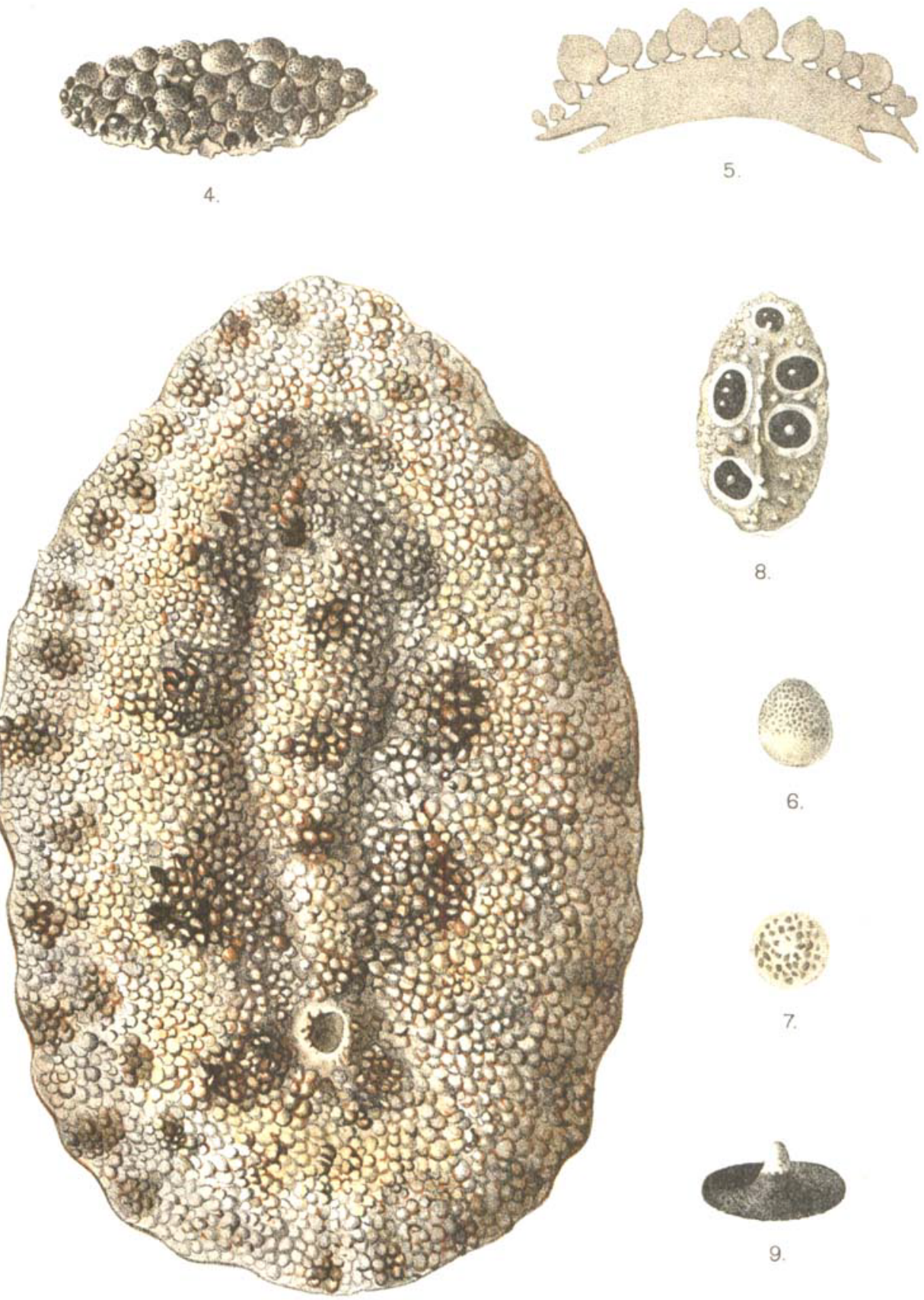

9

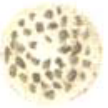

7.

6.

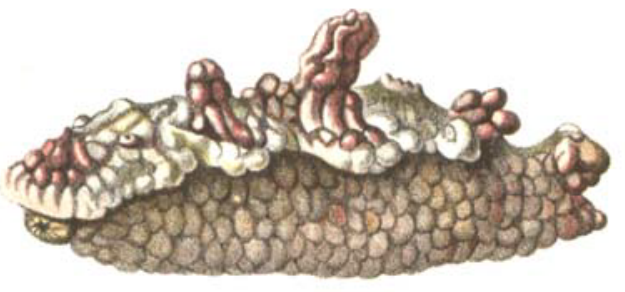

II.
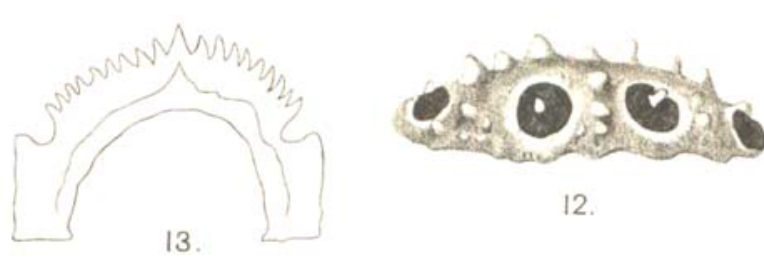

12. 